\title{
Upaya Penghilangan Rasa Pahit Tepung Biji Kelor (Moringa oleifera) dan Aplikasinya untuk Pangan Fungsional
}

\section{(Efforts of Debittering Moringa Seed Flour (Moringa oleifera) and It's Application for Functional Food)}

\author{
Muhammad Iqbal Fanani Gunawan*, Endang Prangdimurti, Tjahja Muhandri
}

(Diterima Maret 2020/Disetujui Agustus 2020)

\begin{abstract}
ABSTRAK
Tanaman kelor (Moringa oleifera) merupakan tanaman yang memiliki banyak kegunaan pada setiap bagiannya. Biji kelor memiliki gizi yang tinggi, namun belum dimanfaatkan sebagai bahan pangan karena mengandung glikosida sianogenat dan memiliki rasa yang pahit. Penelitian ini bertujuan untuk mendapatkan metode terbaik dalam menghilangkan rasa pahit dan sianida biji kelor, menganalisis kadar gizi proksimat dan kapasitas antioksidan, serta tingkat penerimaannya pada saat diaplikasikan pada produk kukis. Penelitian ini menggunakan perlakuan perbedaan jenis larutan perendam (air, $\mathrm{NaCl} 3,5 \%$, larutan $\mathrm{CH}_{3} \mathrm{COOH} 1 \mathrm{~N}$, dan $\mathrm{NaHCO}_{3} 0,5 \%$ ) dan perbedaan suhu pemanasan $\left(70^{\circ} \mathrm{C}\right.$, suhu air mendidih $\left( \pm 97^{\circ} \mathrm{C}\right)$, dan perebusan bertekanan $\left( \pm 115^{\circ} \mathrm{C}\right)$ ). Tepung biji kelor dengan perlakuan perendaman $\mathrm{NaHCO}_{3}$ yang dilanjutkan dengan perebusan bertekanan selama 35 menit dipilih menjadi tepung terbaik karena memiliki kadar sianida terendah, intensitas rasa pahit yang berkurang, serta nilai FRAP (Ferric Reducing Antioxidant Power) tertinggi (33,40 $\pm 1,22 \mathrm{mg} / \mathrm{kg} ; 3,40 \pm 1,24 ;$ dan $58,70 \pm 2,67 \mathrm{mg} \mathrm{AEAC} / \mathrm{g})$ dibandingkan dengan tepung tanpa perlakuan $(152,15 \pm 0,95 \mathrm{mg} / \mathrm{kg} ; 10,29 \pm 2,92$; dan $17,43 \pm 1,22 \mathrm{mg} \mathrm{AEAC} / \mathrm{g})$. Tepung yang terpilih digunakan sebagai pensubstitusi terigu $(0 \%, 10 \%, 20 \%$, dan $30 \%)$ pada pembuatan kukis. Analisis sensori rating hedonik pada kukis menggunakan 60 orang panelis. Substitusi hingga $30 \%$ secara umum tidak memiliki perbedaan penerimaan sensori dibandingkan kontrol (0\%), kecuali atribut warna.
\end{abstract}

Kata kunci: Moringa oleifera, pangan fungsional, pahit, sianida, tepung biji kelor

\section{ABSTRACT}

Moringa oleifera is a plant that has many benefits in each part. Moringa seeds have high nutrient content but they have not been used as food ingredients because it contains cyanigenic glycoside and a bitter taste. This study aims to obtain the best method in eliminating the bitter taste and cyanide of moringa seeds, analyzing its proximate nutritional levels and antioxidant capacity, and the level of acceptance when it's applied to cookie products. This study used different types of soaking solution (water, $3.5 \% \mathrm{NaCl}, 1 \mathrm{~N} \mathrm{CH}_{3} \mathrm{COOH}$ solution, and $0.5 \% \mathrm{NaHCO}_{3}$ ) and boiling temperature $\left(70^{\circ} \mathrm{C}\right.$, boiling water temperature $\left( \pm 97^{\circ} \mathrm{C}\right)$, and pressure boiling $\left.\left( \pm 115^{\circ} \mathrm{C}\right)\right)$. Flour with $\mathrm{NaHCO}_{3}$ immersion treatment continued by pressurized boiling for 35 minutes was chosen to be the best flour because it had the lowest cyanide content, reduced bitter taste, and the highest FRAP (Ferric Reducing Antioxidant Power) values $(33.40 \pm 1.22 \mathrm{mg} / \mathrm{kg} ; 3.40 \pm 1.24 \mathrm{mg} / \mathrm{kg}$; and $58.70 \pm 2.67 \mathrm{mg} \mathrm{AEAC} / \mathrm{g})$ compared with untreated moringa seed flour $(152.15 \pm 0.95 \mathrm{mg} / \mathrm{kg} ; 10.29 \pm 2.92 \mathrm{mg} / \mathrm{kg} ;$ and $17.43 \pm 1.22 \mathrm{mg} \mathrm{AEAC} / \mathrm{g})$. The selected flour was used as a substitute for flour $(0 \%, 10 \%, 20 \%$, and $30 \%)$ in cookies making. Sensory hedonic rating analysis on cookies used 60 untrained panelists. Substitution up to $30 \%$ overall did not have a significant difference in acceptance compared to control ( $0 \%)$ except for color attribute.

Keywords: bitter, cyanide, Moringa oleifera, functional food, moringa seed flour

\section{PENDAHULUAN}

Tanaman kelor (Moringa oleifera) merupakan tanaman yang memiliki banyak kegunaan pada setiap bagiannya. Daun kelor telah terbukti memiliki manfaat sebagai bahan pangan tinggi gizi dan komponen fungsional sehingga dapat mencegah malnutrisi. Bagian lain dari tanaman kelor, juga memiliki potensi

Departemen Ilmu dan Teknologi Pangan, Fakultas Teknologi Pertanian, Institut Pertanian Bogor, Kampus IPB Darmaga, Bogor 16680

* Penulis Korespondensi:

Email: iqbal_fanani@apps.ipb.ac.id untuk dijadikan pangan fungsional, namun pemanfaatannya sebagai bahan pangan belum banyak diketahui.

Budi daya kelor semakin ditingkatkan agar masyarakat dapat menanam, mengolah, dan mengonsumsi kelor sebagai bahan pangan tinggi gizi secara mandiri. Salah satu contohnya ialah Peraturan Bupati Sumbawa Barat Nomor 80 Tahun 2017 yang mengatur tentang program penanaman minimal 2 pohon kelor di pekarangan rumah. Tanaman kelor mudah untuk dibudi daya karena tahan terhadap penyakit dan kekeringan (Foidl et al. 2001). Salah satu bagian dari tanaman kelor yang memiliki potensi untuk dimanfaatkan sebagai bahan pangan fungsional adalah biji 
kelor. Ketersediaan biji kelor yang melimpah, yaitu sekitar 25.000 biji yang dihasilkan oleh setiap pohon per tahunnya, dengan bobot rata-rata biji 0,3 gram (Foidl et al. 2001).

Menurut Leone et al. (2016), biji kelor memiliki keunggulan, yaitu kadar minyak sebagai komponen gizi tertinggi di dalamnya sebanyak 36,7\% (basis kering). Minyak biji kelor mengandung asam lemak tidak jenuh oleat yang baik bagi kesehatan hingga 73\% (basis total minyak). Biji kelor mengandung protein yang tinggi mencapai rata-rata $31,4 \%$ (basis kering). Nilai protein biji kelor tidak jauh berbeda dari jumlah protein kedelai, yaitu sebesar 36,49\% (Rizzo \& Baroni 2018). Biji kelor memiliki kadar asam amino metionin dan sistein yang tinggi, mendekati kandungan yang ada dalam pangan hewani, seperti susu dan telur. Biji kelor bebas dari tripsin inhibitor dan aktivitas urease sehingga dapat dipastikan memiliki daya cerna protein tinggi (93\%) (Leone et al. 2016). Biji kelor juga memiliki kapasitas total antioksidan yang lebih tinggi dibandingkan dengan tanaman tropis, seperti kacang kedawung (Parkia biglobosa) dan biji asem buto (Adansonia digitata) (Compaore et al. 2011).

Biji kelor dilaporkan memiliki rasa pahit yang dominan dan sedikit sepat (Ogunsina et al. 2015) sehingga membutuhkan pengolahan awal untuk mengurang rasa pahit. Foidl et al. (2001) menyatakan bahwa di dalam biji kelor terdapat senyawa fitokimia, seperti fenolik, flavonoid, saponin, fitat, glikosida sianogen, dan glukosinolat yang diduga menyumbangkan rasa pahit pada biji kelor.

Glikosida sianogen merupakan metabolit sekunder yang diduga menyumbangkan rasa pahit pada biji kelor pada tumbuhan berupa turunan asam amino. Senyawa ini akan berubah menjadi toksin asam sianida (HCN) ketika terjadi kontak dengan enzim ekstraseluler $\beta$ glikosidase dan hidroksinitril liase akibat kerusakan sel secara fisik (EFSA 2019). Studi yang dilakukan oleh EFSA (2019) menyatakan bahwa dosis oral mematikan akut HCN adalah sebesar 0,5-3,5 mg/kg bobot badan. FSANZ (2004) juga menjelaskan 50-60 mg sianida bebas dalam singkong dan produk pengolahannya merupakan dosis memati-kan bagi pria dewasa.

Biji kelor dilaporkan memiliki kandungan glikosida sianogenat yang cukup rendah, namun senyawa glikosida sianogenat merupakan salah satu prioritas utama yang perlu dihilangkan agar keamanan pangan dapat dipastikan. Kandungan glikosida sianogenat pada biji kelor sebesar 5.0 mg HCN ekuivalen/kg (Foidl et al. 2001). Nilai tersebut tergolong sangat rendah jika dibandingkan dengan regulasi European Community (EC) yang mengatur kadar glikosida sianogenat pada tepung utuh (meal) singkong dan kacang almond $<100$ mg HCN ekuivalen/kg dan tepung utuh (meal) biji rami $<250 \mathrm{mg} \mathrm{HCN}$ ekuivalen/kg (EFSA 2019).

Ogunsina et al. (2015) menambahkan bahwa proses perebusan biji kelor dengan air mendidih selama 35 menit dapat menurunkan rasa pahit pada roti dan kukis. Proses perendaman dalam larutan $\mathrm{NaCl}$ dan $\mathrm{NaHCO}_{3}$ dapat menurunkan rasa pahit pada
Momordica charantia dan Lupinus albus (Rashima et al. 2017b; Ertas dan Bilgicli 2014). Indriasari et al. (2016) menyatakan dengan perebusan $85^{\circ} \mathrm{C}$ selama 7,5 menit mampu menurunkan kom-ponen saponin yang ada dalam daun kelor hingga 3,9\%.

Penelitian ini bertujuan untuk memperoleh teknik pengolahan yang dapat menurunkan kadar sianida dan rasa pahit tepung biji kelor dengan cara melakukan kombinasi proses perendaman dan perebusan berdasarkan beberapa literatur, agar dapat diaplikasikan pada berbagai produk pangan, dalam hal ini kukis. Aplikasi tepung biji kelor tanpa pengolahan pada produk roti dan kukis telah dilakukan sebelumnya oleh Ogunsina et al. (2015) dengan hasil analisis sensori penerimaan menunjukkan bahwa substitusi $20 \%$ merupakan batas penerimaan sensori dan sifat fisik oleh panelis. Berdasarkan hasil dari penelitian ini, substitusi tepung biji kelor diharapkan menjadi lebih tinggi sehingga kukis memiliki kandungan fungsional seperti metionin, sistein, dan asam lemak tidak jenuh yang lebih tinggi.

\section{METODE PENELITIAN}

\section{Tempat Penelitian}

Penelitian dilaksanakan di Pilot Plant SEAFAST (Southeast Asian Food and Agriculture Science and Technology) Center, Laboratorium Sensori, Laboratorium Kimia dan Biokimia Pangan, dan Laboratorium Pengolahan Pangan, Departemen IImu dan Teknologi Pangan, Fakultas Teknologi Pertanian, Institut Pertanian Bogor.

\section{Bahan Penelitian}

Bahan utama yang digunakan adalah biji kelor yang diperoleh dari Kabupaten Kediri, Jawa Timur melalui UD. Agro Sejahtera. Biji kelor tersebut kering dan berwarna cokelat kehitaman.

\section{Pembuatan Tepung Biji Kelor}

Biji kelor hasil sortasi, dikupas menggunakan abrasive polisher untuk diambil bagian intinya (endosperma). Biji kelor dicuci dengan air bersih dan direndam menggunakan air, $\mathrm{NaCl} 3,5 \% \mathrm{w} / \mathrm{v}$, larutan $\mathrm{CH}_{3} \mathrm{COOH} 1 \mathrm{~N}$ v/v, dan $\mathrm{NaHCO}_{3} 0,5 \%$ w/v dengan rasio biji kelor dan air perendam 1:30 w/v selama 24 jam. Biji kelor ditiriskan, dicuci dengan air bersih, lalu dipanaskan dengan air $(1: 5 \mathrm{w} / \mathrm{v})$ pada suhu $70^{\circ} \mathrm{C}$, suhu air mendidih $\left( \pm 97^{\circ} \mathrm{C}\right)$, dan perebusan bertekanan dengan suhu $\pm 115^{\circ} \mathrm{C}$ menggunakan pressure cooker selama 35 menit untuk semua perlakuan (Ogunsina et al. 2015; Rashima et al. 2017a; Hutami \& Harijono 2014; Abou-Zaid \& Ibraheem 2015).

Biji kelor dari masing-masing kelompok perlakuan dikeringkan dalam oven pengering bersuhu $50^{\circ} \mathrm{C}$ selama 24 jam. Biji kering dihancurkan menjadi tepung, dikemas rapat dalam plastik ziplock polipropilen, dan disimpan pada suhu $4^{\circ} \mathrm{C}$ sebelum digunakan untuk analisis. 


\section{Penentuan Tingkat Rasa Pahit Tepung Biji Kelor}

Analisis sensori pengukuran rasa pahit menggunakan rangkaian metode uji rating intensitas rasa pahit berdasarkan Meilgaard et al. (2004) dengan modifikasi Ogunsina et al. (2015) dan Rashima et al. (2017b). Metode ini dilakukan dalam 4 tahap, yaitu tahap seleksi panelis berdasarkan tingkat kesehatan, kepekaan membedakan 5 rasa dasar, dan kepekaan membedakan dan mengurutkan rasa pahit dalam berbagai konsentrasi. Lima belas panelis terpilih selanjutnya mengikuti tahap Focus Group Discussion (FGD) untuk menentukan nilai kuantitatif rasa pahit berdasarkan referensi (kafein). Panelis kemudian memasuki tahap pelatihan kepekaan konsentrasi rasa pahit terhadap nilai kuantitatif konsentrasi yang ditetapkan FGD. Hasil FGD menyatakan konsentrasi 0,$05 ; 0,07 ;$ dan $0,175 \% \mathrm{w} / \mathrm{v}$ digunakan sebagai referensi pada skala dengan nilai 3,5 , dan 15 . Skala yang digunakan adalah skala garis dengan panjang 15 $\mathrm{cm}$. Panelis terlatih kemudian melakukan pengujian sampel secara kuantitatif. Sampel yang digunakan untuk analisis sensori merupakan sampel tepung yang dibuat menjadi agar (Agarpac). Pembuatan agar dengan konsentrasi 1:10 w/v bertujuan supaya panelis mencicipi tepung dalam jumlah yang sama, serta memudahkan panelis dalam mencicipi tepung.

\section{Penentuan Kadar Sianida Tepung Biji Kelor}

Analisis kadar sianida $\left(\mathrm{CN}^{-}\right)$menggunakan metode SNI 6989.77:2011. Prinsip pengukuran kadar sianida ialah dengan cara diubah menjadi sianogen klorida ( $\mathrm{CNCl}$ ) dengan penambahan kloramin $\mathrm{T}$ pada $\mathrm{pH}<8$, kemudian direaksikan dengan pereaksi asam barbutirat-piridin sehingga menghasilkan warna merah kebiru-biruan. Warna tersebut dibaca pada spektrofotometer dengan panjang gelombang $570 \mathrm{~nm}$, kemudian dibandingkan dengan kurva standar KCN.

\section{Analisis Gizi Proksimat dan Kapasitas Antioksidan Tepung Terpilih}

Tiga sampel hasil pengurangan rasa pahit terbaik kemudian dilakukan analisis kandungan proksimat. Analisis proksimat yang meliputi kadar air (metode gravimetri), kadar abu (metode pengabuan kering), kadar lemak (metode soxhlet), dan kadar protein (metode kjeldahl) sesuai dengan AOAC (2012). Kandungan total fenolik metode spektrofotometri pereaksi Folin Ciocalteau berdasarkan ljarotimi et al. (2013) dan kapasitas antioksidan dilakukan dengan metode DPPH (1,1-difenil-2-pikrilhidrazil) dan FRAP (Ferric Reducing Antioxidant Power) (Adedayo et al. 2010; Maryam et al. 2016).

\section{Analisis Sensori Rating Hedonik Kukis dengan Tepung Substitusi}

Satu jenis sampel terbaik berdasarkan analisis kandungan sianida, gizi proksimat, dan kapasitas antioksidan selanjutnya diaplikasikan dalam pembuatan kukis. Analisis rating hedonik kukis substitusi tepung biji kelor menggunakan 60 orang panelis konsumen. Tepung biji kelor kemudian disubstitusikan dengan tepung terigu sebanyak $10 \%, 20 \%$, dan $30 \%$ pada pembuatan kukis. Formulasi kukis yang digunakan, yaitu $100 \mathrm{~g}$ tepung terigu, $60 \mathrm{~g}$ gula bubuk, $15 \mathrm{~g}$ margarin, $3 \mathrm{~g}$ susu skim, $1 \mathrm{~g}$ Na-bikarbonat, 0,75 $\mathrm{g}$ amonium bikarbonat, 1,0 g garam, dan air. Bahanbahan dicampur menggunakan mixer, kemudian dilakukan pemanggangan pada suhu $180^{\circ} \mathrm{C}$ selama 15 menit. Enam puluh panelis konsumen tidak terlatih yang berada di kampus Institut Pertanian Bogor kemudian memberikan penilaian kesukaan pada atribut warna, tekstur, aroma, dan rasa kukis yang diberikan (Ogunsina et al. 2015). Penerimaan setiap atribut berada dalam skala sangat tidak diterima (skala 1) hingga sangat diterima (skala 7 ).

\section{Rancangan Percobaan}

Penelitian ini menggunakan rancangan percobaan acak lengkap faktorial (RALF) dengan 2 faktor percobaan, yaitu jenis larutan perendam (air (W), $\mathrm{NaCl}$ $3,5 \%$ w/v $(S)$, larutan $\mathrm{CH}_{3} \mathrm{COOH} 1 \mathrm{~N} \mathrm{v/v}(A)$, dan $\mathrm{NaHCO}_{3} \quad 0,5 \%$ w/v (B)) dan suhu pemanasan $\left(70^{\circ} \mathrm{C}\right.$ (L), suhu air mendidih $\left( \pm 97^{\circ} \mathrm{C}\right)(\mathrm{H})$, dan perebusan bertekanan $\left.\left( \pm 115^{\circ} \mathrm{C}\right)(\mathrm{HP})\right)$. Perlakuan pembuatan sampel dilakukan sebanyak dua kali ulangan, dan masing-masing dianalisis dengan dua kali pengukuran (duplo). Data yang diperoleh termasuk analisis penerimaan kemudian diolah dengan analisis ragam ANOVA untuk melihat beda nyata dengan taraf signifikasi $5 \%$. Uji lanjut Duncan untuk melihat perbedaan dan membandingkan antarmasing-masing sampel perlakuan. Korelasi penurunan kadar sianida, dan penghilangan rasa pahit akibat kenaikan suhu pemanasan menggunakan uji Pearson dengan taraf signifikansi $5 \%$. Pengolahan data penelitian ini menggunakan program IBM SPSS 20.

\section{HASIL DAN PEMBAHASAN}

\section{Tingkat Rasa Pahit Kuantitatif dan Kadar Sianida Biji Kelor}

Hasil pengujian rasa pahit pada Tabel 1 menyatakan bahwa semua perlakuan perendaman yang diikuti dengan perebusan dapat mengurangi intensitas rasa pahit yang signifikan $(P<0,05)$. Uji lanjut Duncan (Tabel 1) menunjukkan bahwa biji kelor dengan semua jenis perlakuan perendaman dan perebusan memiliki penurunan intensitas rasa pahit yang signifikan dibandingkan dengan tepung biji kelor tanpa perlakuan. Sampel dengan perlakuan perendaman air yang dilanjutkan dengan perebusan bertekanan memiliki nilai rasa pahit terendah, yaitu sebesar 1,19 $\pm 0,92$, jauh lebih rendah dibandingkan dengan nilai rasa pahit tepung tanpa perlakuan, yaitu sebesar $10,29 \pm 2,92$. Kadar sianida terendah terdapat pada perlakuan $\mathrm{NaHCO}_{3}$ dengan perebusan bertekanan, yaitu sebesar $33,40 \pm 1,22 \mathrm{mg} / \mathrm{kg}$ biji kelor yang berbeda signifikan dari semua perlakuan lain. 
Tabel 1 Nilai rasa pahit kuantitatif dan kadar sianida pada biji kelor

\begin{tabular}{|c|c|c|c|}
\hline \multirow[b]{2}{*}{ Jenis larutan perendam } & \multirow[b]{2}{*}{ Suhu perebusan $\left({ }^{\circ} \mathrm{C}\right)$} & \multicolumn{2}{|c|}{ Analisis } \\
\hline & & Rasa pahit* & $\begin{array}{c}\text { Kadar sianida (mg/kg } \\
\text { tepung) }\end{array}$ \\
\hline \multirow[t]{2}{*}{ Tanpa perlakuan $(\mathrm{K})$} & & $10,29 \pm 2,92 \mathrm{e}$ & $152,15 \pm 0,95^{k}$ \\
\hline & $70(\mathrm{~L})$ & $4,69 \pm 1,24 d$ & $109,44 \pm 1,59 h$ \\
\hline \multirow[t]{3}{*}{ Air (W) } & $\pm 97(\mathrm{H})$ & $2,85 \pm 1,53 a b c$ & $92,56 \pm 0,90$ e \\
\hline & $\pm 115(\mathrm{HP})$ & $1,19 \pm 0,92 \mathrm{a}$ & $70,88 \pm 1,93 b$ \\
\hline & $70(\mathrm{~L})$ & $3,47 \pm 2,25 \mathrm{~cd}$ & $117,33 \pm 0,49$ \\
\hline \multirow[t]{3}{*}{$\mathrm{NaCl}(3,5 \%)(\mathrm{S})$} & $\pm 97(\mathrm{H})$ & $3,00 \pm 1,69 \mathrm{bcd}$ & $76,58 \pm 0,72^{c}$ \\
\hline & $\pm 115(\mathrm{HP})$ & $2,24 \pm 1,78 \mathrm{abc}$ & $82,28 \pm 0,15^{d}$ \\
\hline & $70(\mathrm{~L})$ & $2,78 \pm 2,09 a b c$ & $103,26 \pm 0,51 \mathrm{~g}$ \\
\hline \multirow[t]{2}{*}{$\mathrm{NaHCO}_{3}(0,5 \%)(\mathrm{B})$} & $\pm 97(\mathrm{H})$ & $4,07 \pm 2,96 \mathrm{~cd}$ & $70,30 \pm 0,36 b$ \\
\hline & $\begin{array}{l} \pm 115(\mathrm{HP}) \\
70(\mathrm{~L})\end{array}$ & $\begin{array}{l}3,40 \pm 1,24 \mathrm{~cd} \\
3,15 \pm 1,85 \mathrm{bcd}\end{array}$ & $\begin{array}{l}33,40 \pm 1,22 \mathrm{a} \\
132,13 \pm 1,59 \mathrm{j}\end{array}$ \\
\hline \multirow[t]{2}{*}{$\mathrm{CH}_{3} \mathrm{COOH}(1 \mathrm{~N})(\mathrm{A})$} & $\pm 97(\mathrm{H})$ & $1,61 \pm 1,30 \mathrm{ab}$ & $99,40 \pm 0,26^{f}$ \\
\hline & $\pm 115(\mathrm{HP})$ & $2,05 \pm 1,32 a b c$ & $106,73 \pm 3,69 \mathrm{~h}$ \\
\hline
\end{tabular}

Proses perebusan telah dibuktikan dapat mengurangi rasa pahit yang terdapat dalam paria $(M$. charantia), kacang lupin ( $L$. albus), dan biji kelor ( $M$. oleifera) (Rashima et al. 2017b; Ertas \& Bilgicli 2014; Ogunsina et al. 2015). Proses perebusan bertujuan untuk melunakkan tekstur biji kelor, membantu mengikat dan memisahkan antigizi dan komponen fitokimia polar pada biji, serta inaktivasi enzim $\beta$ glikosidase. Enzim $\beta$-glukosidase linamarase pada singkong dilaporkan aktif pada suhu $50^{\circ} \mathrm{C}$ dan stabil pada suhu $40-50^{\circ} \mathrm{C}$ (Nwokoro \& Anya 2011). Inaktivasi enzim $\beta$-glukosidase oleh proses perebusan saja menjadi berbahaya jika tidak diikuti dengan proses lain karena glikosida sianogenat tidak dapat dipecah ketika masuk ke dalam tubuh, sehingga difermentasi oleh bakteri usus menjadi HCN (Reis et al. 2019). Proses lain seperti pengecilan ukuran, pengupasan, dan perendaman menjadi sangat dibutuhkan untuk mengubah glikosida sianogenat menjadi HCN yang mudah larut.

Perendaman dalam $\mathrm{NaCl}$ terbukti menurunkan rasa pahit dalam paria (M. charantia) akibat dari rasa asin yang mampu menutupi rasa pahit (Rashima et al. 2017b). Perlakuan perendaman $\mathrm{NaHCO}_{3}$ memiliki rasa pahit yang tidak berkorelasi dengan penambahan suhu perebusan. Residu $\mathrm{NaHCO}_{3}$ yang terlalu banyak dapat menimbulkan rasa pahit seperti sabun (Herpandi et al. 2019).

Tabel 1 menjelaskan bahwa proses perendaman dengan $\mathrm{NaHCO}_{3}$ dengan perebusan bertekanan merupakan metode yang paling efektif untuk menurunkan kadar sianida dibandingkan dengan perlakuan lain $(33,40 \pm 1,22 \mathrm{mg} / \mathrm{kg}$ tepung). Glikosida sianogenat dalam biji kelor diduga terhidrolisis oleh enzim $\beta$ glukosidase menjadi bentuk sianohidrin apabila terjadi kontak dengan air. Sianohidrin dalam larutan alkali akan terurai menjadi bentuk campuran karbonil dan HCN bebas yang mudah larut dalam air (Hutami dan Harijono 2014). Enzim $\beta$-glukosidase linamarase dilaporkan memiliki aktivitas maksimum pada $\mathrm{pH} 4.5$, dan stabil pada rentang pH 5,0-6,0 (Nwokoro \& Anya
2011). Apabila enzim $\beta$-glukosidase yang terdapat dalam biji kelor diasumsikan memiliki karakteristik sesuai dengan linamarase pada singkong, maka diduga kerja enzim $\beta$-glukosidase tidak optimal dalam kondisi $\mathrm{pH}$ basa $(8,04-8,64)$. Belum ada penelitian yang menjelaskan jenis glikosida sianogenat dan karakteristik enzim $\beta$-glukosidase yang ada dalam biji kelor secara spesifik.

Kondisi larutan alkalis diduga berpengaruh pada kondisi matriks biji kelor. Suasana air rendaman yang alkalis menyebabkan pelunakan jaringan biji, yang mempermudah proses pengeluaran glikosida sianogenat menuju air rendaman (Hutami \& Harijono 2014). Suasana air rendaman yang alkalis menyebabkan pelunakan karena terjadi kerusakan pada ikatan a (1-4) glikosidik di antara asam galakturonat pektin. Prinsip pelunakan jaringan tersebut diterapkan dalam proses pengupasan (lye peeling), yang dilakukan dengan proses perendaman menggunakan larutan alkali pada suhu tinggi (Kumar et al. 2019). $\mathrm{NaHCO}_{3}$ dapat bereaksi dengan air dan terurai menjadi $\mathrm{NaOH}$ dan $\mathrm{H}_{2} \mathrm{CO}_{3}$ yang tidak stabil. $\mathrm{H}_{2} \mathrm{CO}_{3}$ kemudian terurai menjadi $\mathrm{H}_{2} \mathrm{O}$ dan $\mathrm{CO}_{2} . \mathrm{CO}_{2}$ diduga terjebak dalam matriks biji kelor sehingga terjadi ekspansi volume dan membentuk rongga (Putranto et al. 2013) yang memudahkan glikosida sianogenat keluar dari sel dan larut dalam air rendaman.

Faktor suhu dan larutan perendam memberikan pengaruh yang nyata pada kadar sianida $(P<0,05)$. Faktor suhu memberikan pengaruh yang nyata pada intensitas rasa pahit $(P<0,05)$, tetapi faktor jenis larutan perendam tidak memberikan pengaruh nyata pada intensitas rasa pahit $(P>0,05)$. Kedua faktor (suhu dan jenis perendam) memiliki pengaruh interaksi pada intensitas rasa pahit dan kadar sianida. Hal tersebut menunjukkan bahwa kombinasi larutan perendaman dan perebusan berpengaruh nyata pada kadar sianida dan intensitas rasa pahit, namun faktor jenis larutan perendam saja tidak memberikan pengaruh nyata pada intensitas rasa pahit. 
Dugaan awal penelitian ini adalah semakin tinggi suhu pemanasan akan menghilangkan rasa pahit dan kadar sianida dari tepung biji kelor. Berdasarkan uji Pearson, korelasi antara penurunan kadar sianida dan rasa pahit tidak signifikan pada taraf signifikansi 5\% $(P>0,05)$, tetapi kenaikan suhu dan penurunan kadar sianida dan rasa pahit memiliki korelasi yang signifikan pada taraf signifikansi 5\% $(P<0,05)$ Hal tersebut membuktikan bahwa penghilangan sianida tidak memiliki korelasi dengan penghilangan rasa pahit. Penurunan sianida tidak memberikan pengaruh nyata pada rasa pahit yang terdapat dalam biji kelor sehingga diduga sianida tidak menyumbangkan rasa pahit yang dominan pada biji kelor. Suhu perebusan yang semakin tinggi memberikan pengaruh yang nyata pada penurunan rasa pahit dan kadar sianida.

\section{Kandungan Gizi Proksimat, Kapasitas Antioksidan, dan Total Fenolik Biji Kelor Terpilih}

Berdasarkan hasil pada tahap 1, dipilih 3 perlakuan terbaik dengan rasa pahit dan kadar sianida terendah. Perlakuan terpilih adalah perendaman dengan air, $\mathrm{NaCl}$, dan $\mathrm{NaHCO}_{3}$ yang dilanjutkan dengan perebusan bertekanan. Tepung dengan perlakuan perendaman $\mathrm{CH}_{3} \mathrm{COOH}$ yang dilanjutkan dengan perebusan $90^{\circ} \mathrm{C}$ memiliki intensitas rasa pahit terendah, tetapi kadar sianida sampel tersebut cukup tinggi sehingga tidak terpilih untuk uji tahap 2. Ketiga perlakuan tersebut kemudian dilakukan pengukuran kandungan gizi proksimat, kapasitas antioksidan, dan total fenolik. Hasil dari ketiga analisis tersebut ditunjukkan pada Tabel 2.

Hasil uji One Way ANOVA menunjukkan bahwa terdapat perbedaan yang signifikan antara kadar protein, lemak, karbohidrat, air, kapasitas antioksidan, dan total fenolik pada masing-masing sampel $(P<0,05)$ sehingga diperlukan uji lanjut Duncan. Tabel 2 menunjukkan bahwa secara umum kadar protein dan lemak mengalami penurunan setelah diberi perlakuan perendaman dan perebusan. Proses penurunan rasa pahit dengan perendaman dan perebusan telah terbukti berpengaruh pada kadar proksimat dan kapasitas antioksidan. Hal tersebut dijelaskan oleh Rashima et al. (2017a) yang merendam Momordica charantia dalam $\mathrm{NaCl} 3,5 \%$ (60 menit) ditambah dengan blansir $\left(96^{\circ} \mathrm{C}\right.$ selama 3 menit). Kapasitas antioksidan DPPH mengalami kenaikan signifikan, sedangkan FRAP terjadi penurunan signifikan dan tidak terjadi perubahan signifikan pada total fenol (32,81 $\pm 1,83 \mathrm{mg} \mathrm{GAE} / 100 \mathrm{~mL})$. Ogunsina et al. (2015) melakukan perebusan biji Moringa oleifera dalam air selama 35 menit menunjukkan kadar protein, lemak, abu, dan serat dalam bobot kering secara berurutan adalah sebesar 32,68; 33,50; 3,52; dan 4,5\%.

Perlakuan perendaman dengan garam $\mathrm{NaCl}(\mathrm{SHP})$ menyebabkan terjadinya penurunan protein yang signifikan dibandingkan dengan perendaman dengan air (WHP) dan $\mathrm{NaHCO}_{3}$ (BHP). Hal tersebut diduga diakibatkan oleh proses salting in protein oleh larutan garam (Winarno 2004). Proses ini menyebabkan daya larut protein meningkat pada air garam sehingga ikut terbuang bersama air perendam. Penurunan kadar protein dan lemak pada perlakuan perendaman $\mathrm{NaHCO}_{3}$ diduga disebabkan oleh efektivitas $\mathrm{NaHCO}_{3}$ dalam membuka struktur matriks biji kelor. $\mathrm{NaHCO}_{3}$ dapat bereaksi dengan air dan terurai menjadi $\mathrm{NaOH}$ dan $\mathrm{H}_{2} \mathrm{CO}_{3}$ yang tidak stabil. $\mathrm{H}_{2} \mathrm{CO}_{3}$ kemudian terurai menjadi $\mathrm{H}_{2} \mathrm{O}$ dan $\mathrm{CO}_{2}$. $\mathrm{CO}_{2}$ diduga terjebak dalam matriks biji kelor sehingga terjadi ekspansi volume dan membentuk rongga (Putranto et al. 2013) sehingga kandungan yang ada di dalamnya lebih mudah terekstrak dan larut dalam air perebusan.

Pembentukan rongga dalam matriks oleh perendaman $\mathrm{NaHCO}_{3}$ diduga mempermudah komponen antioksidan larut dalam pelarut untuk analisis. Pernyataan tersebut didukung oleh Qin et al. (2013) yang melakukan perendaman gandum kuda (Fagopyrum esculentum) berkecambah dalam $\mathrm{NaHCO}_{3}$ selama 96 jam dalam berbagai konsentrasi. Perendaman dalam $\mathrm{NaHCO}_{3}$ meningkatkan total flavonoid, total fenolik, dan kapasitas antioksidan DPPH. Nilai FRAP dan total fenolik dengan perlakuan memiliki nilai yang lebih tinggi dibandingkan dengan tepung tanpa perlakuan. Menurut Li et al. (2015),

Tabel 2 Kadar proksimat dan antioksidan tepung biji kelor terpilih

\begin{tabular}{|c|c|c|c|c|}
\hline \multirow{2}{*}{ Analisis } & \multicolumn{4}{|c|}{ Jenis perlakuan } \\
\hline & $\mathrm{K}$ & WHP & SHP & $\mathrm{BHP}$ \\
\hline \multicolumn{5}{|l|}{ Proksimat } \\
\hline Protein (\% bk) & $45,00 \pm 0,21^{c}$ & $40,92 \pm 0.84 b$ & $36,69 \pm 0,600^{a}$ & $40,24 \pm 0,22 b$ \\
\hline Lemak (\% bk) & $34,04 \pm 0,84^{c}$ & $30,04 \pm 0,70 b$ & $34,45 \pm 0,08^{c}$ & $29,06 \pm 0,15^{a}$ \\
\hline Karbohidrat (\% bk) & $17,34 \pm 0,68^{a}$ & $25,67 \pm 0,26^{b}$ & $25,29 \pm 0,68^{b}$ & $27,25 \pm 0,27^{c}$ \\
\hline Air (\% bb) & $6,67 \pm 0,10^{b}$ & $6,38 \pm 0,14$ & $7,27 \pm 0,26^{c}$ & $6,77 \pm 0,12^{b}$ \\
\hline Abu (\% bk) & $3,63 \pm 0,24 a$ & $3,37 \pm 0,17 a$ & $3,57 \pm 0,06 a$ & $3,44 \pm 0,24 a$ \\
\hline \multicolumn{5}{|c|}{$\begin{array}{l}\text { Kapasitas antioksidan } \\
\text { (mg AEAC /g bk) }\end{array}$} \\
\hline DPPH & $11,70 \pm 1,11^{c}$ & $3,07 \pm 0,08^{a}$ & $10,36 \pm 2,53^{c}$ & $7,22 \pm 1,11^{b}$ \\
\hline FRAP & $17,43 \pm 1,22$ a & $50,10 \pm 1,69 c$ & $32,38 \pm 2,82 b$ & $58,70 \pm 2,67 d$ \\
\hline $\begin{array}{l}\text { Total fenolik } \\
\text { (mg GAE /g bk) }\end{array}$ & $18,13 \pm 0,42 a$ & $20,22 \pm 0,24 b$ & $27,33 \pm 1,50^{c}$ & $26,48 \pm 1,35^{c}$ \\
\hline
\end{tabular}

Keterangan: K= Sampel tanpa perlakuan; $\mathrm{WHP}=$ Perendaman air dengan perebusan bertekanan; $\mathrm{SHP}=\mathrm{Perendaman} \mathrm{NaCl}$ dengan perebusan bertekanan; $\mathrm{BHP}=$ Perendaman $\mathrm{NaHCO}_{3}$ dengan perebusan bertekanan. Nilai dengan huruf pada baris yang sama menunjukkan tidak ada perbedaan nyata $(P>0,05)$. 
adanya pemanasan (blansir) menghambat enzim polifenoloksidase sehingga mencegah terjadinya proses oksidasi. Komponen antioksidan yang tidak ikut teroksidasi enzim dapat memerangkap radikal bebas. Biji kelor memiliki komponen antioksidan kelompok flavonoid Kaempferol dengan mekanisme transfer elektron (Single Electron Transfer). Biji kelor juga memiliki komponen flavonoid katekin, epikatekin, dan asam fenolik, seperti asam galat dan asam kafeat (Leone et al. 2016; Santos-Sanchez et al. 2019), yang merupakan antioksidan dengan mekanisme transfer Hidrogen (Hydrogen Atom Transfer). Nilai FRAP yang lebih tinggi dari DPPH diduga karena kandungan antioksidan yang mendonorkan elektron pada biji kelor lebih banyak dibandingkan donor hidrogen.

\section{Rating Hedonik Kukis dengan Tepung Biji Kelor Substitusi}

Berdasarkan kandungan gizi proksimat, kapasitas antioksidan (DPPH dan FRAP), dan total fenolik, perlakuan perendaman $\mathrm{NaHCO}_{3}$ dengan perebusan bertekanan (BHP) menjadi perlakuan terpilih untuk dilanjutkan dalam tahap analisis rating hedonik. Hal tersebut disebabkan karena secara umum memiliki nilai gizi proksimat dan kapasitas antioksidan tertinggi, serta memiliki kadar sianida terendah dari semua perlakuan. Tepung BHP dipilih untuk tahap ketiga karena memiliki kadar sianida yang jauh lebih rendah dibandingkan tepung SHP. Tepung biji kelor dengan perlakuan BHP kemudian dilakukan substitusi ke dalam tepung terigu sebanyak $0,10,20$, dan $30 \%$ dalam pembuatan kukis. Enam puluh orang panelis konsumen tidak terlatih memberikan penilaian penerimaan pada atribut warna, tekstur, aroma, dan rasa pada skala 1-7. Atribut overall merupakan rerata dari nilai gabungan keempat atribut tersebut. Hasil rating hedonik kukis tepung biji kelor dengan perlakuan BHP dapat dilihat pada Tabel 3.

Hasil rating hedonik menunjukkan bahwa substitusi tepung biji kelor yang telah dilakukan pengurangan rasa pahit masih diterima panelis hingga 30\% untuk atribut aroma, rasa, tekstur, dan overall. Atribut-atribut tersebut tidak memiliki perbedaan yang signifikan $(P>0,05)$ kecuali atribut warna $(P<0,05)$. Uji lanjut Duncan menunjukkan substitusi $30 \%$ memiliki perbedaan penerimaan warna yang signifikan dengan substitusi 0 , 10 , dan $20 \%$. Penilaian panelis menjelaskan bahwa kukis yang terlalu gelap memiliki nilai penerimaan yang lebih rendah. Hal tersebut disebab- kan karena warna tepung biji kelor lebih gelap dibandingkan dengan tepung terigu sehingga semakin banyak persentase substitusi yang diberikan, warna kukis menjadi semakin gelap. Perubahan warna tidak memberikan pengaruh yang besar karena komponen warna dapat disesuaikan dengan keinginan konsumen menggunakan pewarna alami. Secara overall, keempat jenis subtitusi berada dalam nilai $4,70 \pm 0,93$ sampai $5,06 \pm 0,80$ yang dapat diinterpretasikan sebagai nilai Netral-Bisa diterima.

Kukis substitusi tepung biji kelor memiliki potensi kandungan protein yang lebih tinggi dengan penambahan asam amino sulfur (metionin dan sistein) dan kandungan asam lemak oleat yang lebih tinggi. Metionin merupakan asam amino esensial yang berperan dalam biosintesis sistein dalam tubuh. Metionin sebagai donor metil dalam pembentukan homosistein, yang kemudian mampu bereaksi dengan serin membentuk sistation yang dipecah menjadi $\alpha$ ketobutirat dan sistein (trans-sulfurasi). Sistein merupakan komponen antioksidan endogen glutation ( $\mathrm{\gamma}-$ glutamylcysteinylglycine, GSH). Glutation dideskripsikan sebagai agen pertahanan tubuh terhadap racun xenobiotik, yang berupa obat-obatan, polutan, dan karsinogen. Wood et al. (1993) menjelaskan bahwa golongan MUFA (Mono Unsaturated Fatty Acid) termasuk asam lemak oleat dapat menurunkan kolesterol LDL dan meningkatkan kolesterol HDL lebih besar dibandingkan dengan Omega-3 dan Omega-6 (PUFA). Semakin kecil rasio kolesterol LDL/kolesterol HDL, semakin besar juga kapasitas menghambat terjadinya arterosklerosis.

\section{KESIMPULAN}

Perlakuan pengupasan, perendaman (media air, $\mathrm{NaCl}, \mathrm{NaHCO}_{3}, \mathrm{CH}_{3} \mathrm{COOH}$ ) selama 24 jam dan perebusan (suhu $\pm 70, \pm 97$ dan $\pm 115^{\circ} \mathrm{C}$ ) selama 35 menit, mampu menurunkan rasa pahit biji kelor secara signifikan $(\mathrm{P}<0,05)$. Perendaman dalam $\mathrm{NaHCO}_{3}$ selama 24 jam dilanjutkan dengan perebusan bertekanan $\left( \pm 115^{\circ} \mathrm{C}\right)$ selama 35 menit merupakan perlakuan terbaik dalam menurunkan kadar sianida biji kelor. Perlakuan tersebut juga masih memiliki kandungan gizi dan antioksidan yang cukup tinggi, sehingga dipilih untuk menjadi tepung yang diaplikasikan pada pembuatan kukis. Substitusi tepung terigu dengan $30 \%$ tepung biji kelor perlakuan terbaik

Tabel 3 Hasil analisis sensori rating hedonik tepung biji kelor substitusi

\begin{tabular}{|c|c|c|c|c|c|}
\hline \multirow{2}{*}{$\begin{array}{c}\text { Persen } \\
\text { substitusi (\%) }\end{array}$} & \multicolumn{5}{|c|}{ Atribut } \\
\hline & Aroma & Warna & Rasa & Tekstur & Overall \\
\hline 0 & $5,03 \pm 1,25^{a}$ & $5,52 \pm 1,13^{b}$ & $5,73 \pm 1,27^{a}$ & $3,95 \pm 1,57 a$ & $5,06 \pm 0,80^{a}$ \\
\hline 10 & $5,00 \pm 1,46 a$ & $5,25 \pm 1,37 b$ & $5,38 \pm 1,30 \mathrm{a}$ & $4,10 \pm 1,65^{a}$ & $4,93 \pm 1,01 \mathrm{a}$ \\
\hline 20 & $4,57 \pm 1,66$ a & $5,07 \pm 1,53 b$ & $5,62 \pm 1,12 \mathrm{a}$ & $4,43 \pm 1,54 a$ & $4,92 \pm 1,00 \mathrm{a}$ \\
\hline 30 & $4,43 \pm 1,79 a$ & $4,52 \pm 1,59 a$ & $5,50 \pm 1,20 a$ & $4,33 \pm 1,48$ & $4,70 \pm 0,93 a$ \\
\hline
\end{tabular}

Keterangan: Penerimaan setiap atribut dari skala sangat tidak diterima hingga sangat diterima yang kemudian dikonversikan menjadi nilai 1-7. Nilai dengan huruf pada kolom yang sama menunjukkan tidak ada perbedaan nyata $(P>0,05)$. 
masih memberikan tingkat penerimaan yang tidak berbeda signifikan $(P>0.05)$ dibandingkan dengan tepung tanpa substitusi kecuali atribut warna.

\section{DAFTAR PUSTAKA}

Abou-Zaid FOF, Ibraheem AA. 2015. Using of some different acids in de-bittering of green olives. Journal of Food and Dairy Science. 6(5): 393-404. https://doi.org/10.21608/jfds.2015.48850.

Adedayo BC, Oboh G, Akindahusi AA. 2010. Changes in the total phenol content and antioxidant properties of pepperfruit (Dennettia tripetala) with ripening. African Journal of Food Science. 4(6): 403-409.

[AOAC] Association of Official Analytical Chemist. 2012. Official Methods of Analysis of The Association of Analytical Chemist. Arlington: The Association of Official Analytical Chemist, Inc.

[BSN] Badan Standardisasi Nasional. 2011. Air dan air limbah - Bagian 77: Cara uji sianida $\left(\mathrm{CN}^{-}\right)$secara spektrofotometri. SNI 6989.77:2011.

Compaore WR, Nikiema PA, Bassole HIN, Savadogo A, Mouecoucou J, Hounhouigan DJ, Traore SA. 2011. Chemical composition and antioxidative properties of seeds of Moringa oleifera and pulps of Parkia biglobosa and Adansonia digitata commonly used in food fortification in Burkina Faso. Current Research Journal of Biological Sciences 3(1): 64-72.

[EFSA] European Food Safety Authority. 2019. Evaluation of the health risks related to the presence of cyanogenic glycosides in foods other than raw apricot kernels. European Food Safety Authority Journal. 17(4): 5662.

Ertas N, Bilgicli N. 2014. Effect of different debittering processes on mineral and phytic acid content of lupin (Lupinus albus L.) seeds. Journal of Food Science and Technology. 51(11): 3348-3354. https://doi.org/10.1007/s13197-012-0837-2.

Foidl N, Makkar HPS, Becker K. 2001. The potential of Moringa oleifera for agricultural and industrial uses. In: What development potential for Moringa products?. Dar Es-Salaam, Tanzania, October 20th - November 2nd 2001.

[FSANZ] Food Standards Australia New Zealand. 2004. Cyanogenic Glycosides In Cassava And Bamboo Shoots: A Human Health Risk Assessment. Technical Report Series No. 28. [internet]. [diunduh pada 3 Februari 2020]. Tersedia pada: https://www.foodstandards.gov.au/ publications/documents/28_Cyanogenic_glycoside s.pdf.
Herpandi, Widiastuti I, Wulandari, Sari CA. 2019. Efektivitas natrium bikarbonat $\left(\mathrm{NaHCO}_{3}\right)$ terhadap karakteristik fisikokimia dan sensori keripik tulang ikan putak (Notopterus notopterus). Jurnal Pengolahan Hasil Perikanan Indonesia. 22(2): 263-272. https://doi.org/10.17844/jphpi.v22i2. 27676.

Hutami FD, Harijono. 2014. Pengaruh penggantian larutan dan konsentrasi $\mathrm{NaHCO}_{3}$ terhadap penurunan kadar sianida pada pengolahan tepung ubi kayu. Jurnal Pangan dan Agroindustri. 2(4): 220-230.

ljarotimi OS, Adeoti OA, Ariyo O. 2013. Comparative study on nutrient composition, phytochemical, and functional characteristic of raw, germinated and fermented Moringa oleifera seed flour. Food Science and Nutrition. 1(6): 452-463. https:// doi.org/10.1002/fsn3.70.

Indriasari Y, Wignyanto, Kumalaningsih S. 2016. Effect of blanching on saponins and nutritional content of moringa leaves extract. Journal of Food Research. 5(3): 55-60. https://doi.org/10.5539/jfr.v5n3p55.

Kabupaten Sumbawa Barat. 2017. Peraturan Bupati Nomor 80 Tahun 2017 tentang Gerakan Menanam dan Melestarikan Kelor di Kabupaten Sumbawa Barat.

Kumar V, Chavan SM, Jain SK, Salvi BL, Jain NK, Kumar A, Meena KK. 2019. Peeling of tough skinned fruits and vegetables: A review. International Journal of Chemical Studies. 7(2): 1825-1829.

Leone A, Spada A, Battezzati A, Schiraldi A, Aristil J, Bertoli S. 2016. Moringa oleifera seeds and oil: characteristics and uses for human health. International Journal of Molecular Sciences. 17: 2141-2155. https://doi.org/10.3390/ijms17122141.

Li Y, Wills RBH, Golding JB. 2015. Sodium chloride, a cost effective partial replacement of calcium ascorbate and ascorbic acid to inhibit surface browning on fresh-cut apple slices. LWT-Food Science and Technology. 64(1): 503-507. https://doi.org/10.1016/j.Iwt.2015.05.010.

Maryam ST, Baits M, Nadia A. 2016. Pengukuran aktivitas antioksidan ekstrak etanol daun kelor (Moringa oleifera) menggunakan metode FRAP. Jurnal Fitofarmaka Indonesia. 2(2): 115-118. https://doi.org/10.33096/jffi.v2i2.181.

Meilgaard M, Civille GV, Carr BT. 2004. Sensory Evaluation Techniques, Fourth Edition. Florida (US): CRC Press LLC.

Nwokoro O, Anya FO. 2011. Linamarase enzyme from Lactobacillus delbrueckii NRRL B-763: purification and some properties of a $\beta$-Glucosidase. Journal of the Mexican Chemical Society. 55(4): 246-250. 
Ogunsina BS, Radha C, Indrani D. 2015. Quality characteristics of bread and cookies enriched with debittered Moringa oleifera seed flour. International Journal of Food Sciences and Nutrition. 62(2): 185-194. https://doi.org/10.3109/09637486.2010. 526928.

Putranto AW, Argo BD, Komar N. 2013. Pengaruh perendaman natrium bikarbonat $\left(\mathrm{NaHCO}_{3}\right)$ dan suhu penggorengan terhadap nilai kekerasan keripik kimpul (Xanthosoma sagittifolium). Jurnal Teknologi Pertanian. 14(2): 105-114.

Qin P, Wu L, Yao Y, Ren G. 2013. Changes in phytochemical compositions, antioxidant and $\alpha$ glucosidase inhibitory activities during the processing of tartary buckwheat tea. Food Research International. 50: 562-567. https:// doi.org/10.1016/j.foodres.2011.03.028.

Rashima SR, Maizura M, Uthumporn U.2017a. Effects of debittering treatments on the physical properties and antioxidant capacity of bitter gourd extracts. Advance Journal of Food Science and Technology. 13(6): 253-261. https://doi.org/10.19026/ ajfst.13.5162.

Rashima SR, Maizura M, Kang WM, Fazilah A, Tan LX. 2017b. Influence of sodium chloride treatment and polysaccharides as debittering agent on the physicochemical properties, antioxidant capacity and sensory characteristics of bitter gourd (Momordica charantia) juice. Journal of Food Science and Technology. 54(1): 228-235. https://doi.org/10.1007/s13197-016-2454-y.

Reis SA, Conceiao LL, Peluzio MCG. 2019. Intestinal microbiota and colorectal cancer: changes in the intestinal microenvironment and their relation to the disease. Journal of Medical Microbiology. 68(10):1391-1407.

Rizzo G, Baroni L. 2018. Soy, Soy Foods and Their Role in Vegetarian Diets. Nutrients. 10(1): 43. https://doi.org/10.3390/nu10010043.

Santos-Sanchez NF, Salas-Coronado R, VillanuevaCanongo C, Hernandez-Carlos B. 2019. Antioxidant Compounds and Their Antioxidant Mechanism. [internet]. [diunduh pada 3 Februari 2020]. Tersedia pada: https://www.intechopen.com/books/anti oxidants/antioxidant-compounds-and-theirantioxidant-mechanism.

Winarno FG. 2004. Kimia Pangan dan Gizi. Jakarta (ID) : Gramedia Pustaka Utama.

Wood R, Kubena K, O'Brien B, Tseng S, Martin G. 1993. Effect of butter, mono-and polysaturated fatty acid-enriched butter, trans fatty acid margarine, and zero trans fatty acid margarine on serum lipids and lipoproteins in healty men. Journal of Lipid Research. 34(1): 1-1. 